\title{
A Critique of Rorty's Conception of Pragmatism
}

Paul Giladi

\section{(e) OpenEdition}

\section{Journals}

Electronic version

URL: http://journals.openedition.org/ejpap/415

DOI: 10.4000/ejpap.415

ISSN: 2036-4091

Publisher

Associazione Pragma

\section{Electronic reference}

Paul Giladi, «A Critique of Rorty's Conception of Pragmatism », European Journal of Pragmatism and American Philosophy [Online], VII-2 | 2015, Online since 23 December 2015, connection on 04 May 2019. URL : http://journals.openedition.org/ejpap/415 ; DOI : 10.4000/ejpap.415

This text was automatically generated on 4 May 2019.

\section{(c) $(1) \odot$}

Author retains copyright and grants the European Journal of Pragmatism and American Philosophy right of first publication with the work simultaneously licensed under a Creative Commons AttributionNonCommercial-NoDerivatives 4.0 International License. 


\title{
A Critique of Rorty's Conception of Pragmatism
}

\author{
Paul Giladi
}

\section{AUTHOR'S NOTE}

I would like to thank Bob Stern and the two anonymous referees for their invaluable feedback on this essay.

\section{Rorty, Pragmatism, and Metaphysics}

1 Rorty understands 'metaphysics' as "a permanent neutral matrix for inquiry." Given the kind of language Rorty uses to characterise metaphysics, ${ }^{2}$ I think it would not be unreasonable to suppose he conceives of 'metaphysics' in terms of Hilary Putnam's notion of 'metaphysical realism.' According to metaphysical realism, "the world consists of some fixed totality of mind-independent objects. There is exactly one true and complete description of 'the way the world is.' Truth involves some sort of correspondence relation between words or thought-signs and external things and sets of things." ${ }^{3}$ The Weltanschauung of the metaphysical realist/metaphysician is expressed by Rorty in the following manner: "For our notion of the world - it will be said - is not a notion of unquestioned beliefs, or unquestionable beliefs, or ideally coherent beliefs, but rather of a hard, unyielding, rigid etre-en-soi which stands aloof, sublimely indifferent to the attentions we lavish upon it." ${ }^{4}$ Such a way of portraying a genus of inquiry principally concerned with establishing a 'God's-eye-view' is summed up by Rorty in a later work: "I use 'metaphysics' as the name of the belief in something non-human which justifies our deep attachments. ${ }^{5}$ By presenting metaphysics as comprising 'non-human' dimensions, where what is 'non-human' appears to refer to something which transcends the locus of social and cultural practice, Rorty regards metaphysics as the great nemesis of pragmatism 
- as he (in)famously writes, "[t]he pragmatist ... does not think of himself as any kind of metaphysician." 6

According to Rorty, pragmatism is the apotheosis of the secular age that runs through Feuerbach, Marx, Nietzsche, and Dewey, where the vocabulary of foundationalism and essentialism had been debunked in favour of a fundamentally different mode of discourse and value-system, where the exigencies of our socio-political and cultural practices are regarded as the proper grounds and indications of meaning and normativity. Crucially, for Rorty, the central aspect of the apparent paradigm shift from the modern era to the 'postmodern' era is the gradual abandonment of traditional categorial/onto-theological dualisms, such as essence/accident, appearance/reality, freedom/nature, mind/body, etc. ${ }^{7}$ Unlike Hegel, who argues that these dualisms can be rejected on the basis that those very dualisms are in fact are capable of being sublated in favour of a dialectical conceptual framework, Rorty thinks that the problem with these binary categories of thought is how they exhibit an allegedly pathological cognitive propensity for regarding normative constraints and the ultimate grounds for the justification of our beliefs as being beyond our practices. ${ }^{8}$ As Carl Sachs writes, "[m]etaphysics, thus understood, consists of the subordination of one's descriptions of the world - one's 'vocabularies,' in Rortyan terms to something beyond all of our normative social practices - something beyond us, to which we are answerable, and which anchors our descriptions of the world, society, and self in something beyond those descriptions." The basic notion of value, according to Rorty, thus undergoes radical critique in the secular age, because we shift from seeing norms as extra-human dictates to seeing norms as, to use Robert Brandom's terminology, "social achievements," ${ }^{10}$ in that what is deemed appropriate or inappropriate in a society is not determined by any completely mind-independent stuff 'out there.' Rather, norms are established by the intersubjective and rational practices between rational agents in a society. In other words, norms get their normative purchase by virtue of being assented to and acknowledged by a community of rational agents. Crucially, though, the practice of assenting to and acknowledging normative constraints and normative entitlements does not involve a crude constructivism or crude anti-realism. What this particular form of social engagement involves is that "the precise content of those implicit norms is determined through a 'process of negotiation' involving ourselves and those who attribute norms to us." ${ }^{11}$ By virtue of being a process of negotiation as opposed to a non-negotiated process, what is deemed appropriate or inappropriate is never fixed but always subject to "further assessment, challenge, defence, and correction." 12

In an obvious way, Rorty's criticism of metaphysics is different to Kantian and Positivist critiques of the science of being-qua-being: unlike the Kantian critique of the metaphysical tradition, Rorty does not aim to expose the amphibolies, paralogisms, antinomies, fallacies of subreption and hypostatisation, and transcendental illusion which are symptomatic of metaphysics; unlike the Logical Empiricist critique of the metaphysical tradition, Rorty does not appeal to any form of verificationist principle, to conclude that metaphysics is meaningless. Rather, Rorty appears to motivate his critique of inquiry into the basic structure of the world on two grounds, grounds which he takes to be pragmatist: (i) methodological-explanatory; and (ii) secular humanist.

4 With regard to (i), Rorty can appeal to the criticisms of Enlightenment rationalism made by William James: 
Rationalism in general thinks it gets the fullness of truth by turning away from sensation to conception, conception obviously giving the more universal and immutable picture. (James 1996: 105)

[The abstract philosophical universe is] far less an account of this actual world than a clear addition built upon it, a classic sanctuary in which the rationalist fancy may take refuge from the intolerably confused and gothic character which mere facts present. It is no explanation of our concrete universe, it is another thing altogether, a substitute for it, a remedy, a way of escape. (James 2000: 15) the fashion at the beginning of the pragmatist school - Hegelian idealism is regarded as its most notorious exponent. Philosophical inquiry, for James and Schiller, must not be conceived of in the way that rationalism characterised philosophical inquiry. While the project of "pure inquiry ${ }^{15}$ aimed to provide substantive conceptions of truth and knowledge by avoiding corporeality and sociality, thereby making metaphysics wholly abstract, James and Schiller conceived of pragmatism as the philosophical school of thought to provide substantive conceptions of truth and knowledge by embedding all human capacities in the world. As James wrote, the most pressing problem with rationalism is that it "seems too buttoned-up and white-chokered and clean-shaven a thing to speak for the vast slow-breathing unconscious Kosmos with its dread abysses and its unknown tides" (James 2003: 146). One can, therefore, see why Rorty partly bases his antirepresentationalism, specifically his rejection of a view of the mind-world relation in terms of our cognitive capacities mirroring a "hard, unyielding, rigid être-en-soi which stands aloof, sublimely indifferent to the attentions we lavish upon it," on James's vocal opposition to Cartesianism. ${ }^{16}$ For example, there is excellent reason to think James here would enthusiastically support Rorty:

A pragmatist turns his back resolutely and once for all upon a lot of inveterate habits dear to professional philosopher. He turns away from abstraction and insufficiency, from verbal solutions, from bad a priori reasons, from fixed principles, closed systems, and pretended absolutes and origins. He turns towards concreteness and adequacy, towards facts, towards action and towards power. (James 2000: 27)

The picture of empirical reality as presented by Cartesianism is of a realm of separate and inert objects, where such objects are governed by strict mechanical laws and constitute a view of nature as being rather "refined," ${ }^{17}$ to use a Jamesian turn-of-phrase. Such a framework is opposed to pragmatism, which does not see the intentional content of our experience as a pastiche of fragmented objects, but rather views our environment as being phenomenologically robust and experientially vibrant. As James writes, "[b]ut I ask you in all seriousness to look abroad on this colossal universe of concrete facts, on their awful bewilderments, their surprises and cruelties, on the wildness which they show, and then to tell me whether 'refined' is the one inevitable descriptive adjective that springs to your lips" (James 2000: 15). For pragmatism, the world of experience, under the Cartesian affection for abstract landscapes, is dead and static, not alive and dynamic. ${ }^{18}$ More basically, the allure of the pragmatist critique of the early modern era, to use an expression from Adrian Moore, is that pragmatism is better able to make sense of things, where it is exactly the practice of sense-making that Rorty thinks metaphysics and ontotheological categorial systems fail to successfully perform in any way at all.

With regard to (ii), Rorty's secular humanist critique of metaphysics, I previously claimed that according to Rorty, the basic notion of value undergoes radical humanist critique in the secular age, because we shift from seeing norms as extra-human dictates to seeing 
norms as social achievements. ${ }^{19}$ Such a shift amounted to the effective abandonment of the metaphysical tradition, insofar as what was symptomatic of metaphysics was its attempt to ground normativity in matters beyond human socio-cultural practice. As Rorty writes:

I wish, just as Conway suggests, 'to reject only that pathological quest for transcendent verities and ahistorical essences' which Plato initiated and Nietzsche mocked. [...] But surely we have already had enough experience with attempts to use the weapons of metaphysics against metaphysics? I think of British empiricism, positivism, contemporary Australian philosophical physicalism, and the like, as such attempts. All they accomplished was to replace one non-human source of justification (the Will of God, the Idea of the Good) with another (the Intrinsic Nature of Physical Reality). (Rorty 2001: 90-1)

8 While the rise of secular humanist axiology principally begins with Nietzsche, Rorty enlists James a key ally in his cultural war against metaphysics and its alleged antihumanism. ${ }^{20}$ For that matter, there appears to be compelling reason to think Rorty is justified to appeal to James:

You see how naturally one comes to the humanistic principle: you can't weed out the human contribution. Our nouns and adjectives are all humanised heirlooms, and in the theories we build them into, the inner order and arrangement is wholly dictated by human considerations. (James 2000: 111-2) ${ }^{21}$

Although Rorty would admonish James for relying on the concept of 'experience, ${ }^{22}$ there is still much in this passage for Rorty to find rather alluring: namely, what James writes in terms of insisting on the ubiquity of intersubjective and socio-historical inquiry seems to anticipate his own vision of a "post-Philosophical culture," ${ }_{23}$ "in which there are no appeals to authority of any kind, including appeals to truth and rationality." ${ }^{44}$ Given how ordinary language, and the vocabulary and norms of both the Naturwissenschaften as well as the Geisteswissenschaften are saturated by human practice, this signifies, for Rorty, that we have not only broken free from a conception of human mindedness as the mirror of nature, but also that we have - to use Nietzsche's term - emerged from the "shadows of God." ${ }^{25}$ In other words, according to Rorty, the great metaphilosophical-cultural consequence of pragmatism and its essential humanist commitments is the resulting dismissal of the remaining pillars of representationalism and rationalism, a metaphysical conception of truth and a metaphysical conception of objectivity. As he writes, "[truth is] not the sort of thing one should expect to have an interesting philosophical theory about",26 "[and we ought to] substitute the idea of 'unforced agreement' for that of 'objectivity'." ${ }^{27}$ In place of metaphysical notions of truth and objectivity, Rorty, who regards himself as the philosophic heir of James and Dewey, proposes a nuanced epistemic theory of truth, one which is not identifiable with a crude idealised warranted assertibility:

For pragmatists, the desire for objectivity is not to escape the limits of one's community, but simply the desire for as much intersubjective agreement as possible, the desire to extend the reference of 'us' as far as we can. (Rorty 1991: 23)

Though Rorty has been roundly criticised for apparently advocating epistemic relativism and showing contempt for any meaningful conception of truth ${ }^{28}$ what he writes here suggests something that in fact places him far closer to Peirce than Rorty officially countenances: the essence of pragmatism is to clarify our philosophical ideas by illustrating and reflecting on their role in our cognitive practices; and to be in a position where we can genuinely clarify our ideas in this specific way requires us to "expand the frontiers of inquiry." ${ }^{29}$ Crucially, though, we expand the frontiers of inquiry by continuously playing the game of giving and asking for reasons, which widens the 
'conversations' 30 between rational enquirers thereby enabling ideas to undergo "further assessment, challenge, defence, and correction." ${ }^{31}$

So far, I have suggested some pragmatist reasons to think Rorty's claim that pragmatism is opposed to metaphysics is justified. However, in what follows, I shall argue that there are more compelling reasons to think Rorty's metaphilosophical characterisation of pragmatism is rather problematic on pragmatic grounds.

\section{Pragmatism and Metaphysics}

12 For all of Rorty's confidence in pragmatism eo ipso being dismissive of metaphysics, Peirce, who is arguably the founder of the pragmatist movement, argues for the indispensability of metaphysics:

Find a scientific man who proposes to get along without any metaphysics - not by any means every man who holds the ordinary reasonings of metaphysicians to scorn - and you have found one whose doctrines are thoroughly vitiated by the crude and uncriticised metaphysics with which they are packed. We must philosophise, said the great naturalist Aristotle - if only to avoid philosophising. (CP: 1.129)

13 Peirce argues that not only is it impossible to avoid metaphysics, but also that to reject metaphysics is to do metaphysics. It is not just that ordinary language is packed with metaphysical concepts, ${ }^{32}$ but even those conservative naturalist attitudes such as positivism and eliminativist varieties of nominalism also contain metaphysical commitments. So, for all of the positivists' and eliminativists' insistence that they have successfully purged inquiry of metaphysics "in the spirit of Newton's 'hypotheses non fingo', ${ }^{33}$ they are committed in some way to the very enterprise that they seek to reject. There is therefore something self-undermining about anti-metaphysics, which shows metaphysics to be indispensable - just as there is something self-undermining about denying the Principle of Non-Contradiction, insofar as to do so itself involves employing the principle. To quote David Oderberg, who would agree with Peirce on this subject:

Natural language is permeated and saturated by metaphysics, and has been so ever since philosophy began with the pre-Socratics. [...] The problem is in thinking that there is a vantage point from which we can espy language in its 'ordinary,' premetaphysical state. There is no such vantage point because there is no such language to be observed in the first place. ${ }^{34}$

The inevitability of metaphysics, therefore, consists in the ubiquity of metaphysical concepts in language..$^{35} \mathrm{~A}$ similar claim is made by Jonathan Lowe, who writes: "[i]n my view, all other forms of inquiry rest upon metaphysical presuppositions - thus making metaphysics unavoidable - so that we should at least endeavour to do metaphysics with our eyes open, rather than allowing it to exercise its influence upon us at the level of uncritical assumption." ${ }^{36}$

However, in response to this argument from Peirce, Rorty may claim that confidence in interpreting Peirce as a defender of metaphysics is rather premature, as the following passage appears to indicate:

It will serve to show that almost every proposition of ontological metaphysics is either meaningless gibberish [...] or else is downright absurd; so that all such rubbish being swept away, what will remain of philosophy will be a series of problems capable of investigation by the observational methods of the true sciences. (CP: 5.423) 
The apparent proto-positivism and scientism of Peirce's position also appears in other areas of his philosophical writings: ${ }^{37}$

Everybody uses the scientific method about a great many things, and only ceases to use it when he does not know how to apply it. Experience of the method has not led me to doubt it, but, on the contrary, scientific investigation has had the most wonderful triumphs in the way of settling opinion. (EP: 1.121)

Both the content and tone of these passages from Peirce can be reasonably taken as a staunch defence of scientistic naturalism, a defence which would be especially welcome in certain corners of the Anglo-American naturalist community. For example, Michael Shermer, Peter Atkins, and Alex Rosenberg are three notable thinkers who adopt scientism with pride. To quote Shermer on this point: "[s]cientism is a scientific worldview that encompasses natural explanations for all phenomena, eschews supernatural explanations, and embraces empiricism and reason as the twin pillars of a philosophy of life suitable for an Age of Science." ${ }^{38}$ Compare this with Atkins's claim that "science, with its currently successful pursuit of universal competency [...] should be acknowledged king." ${ }^{39}$ And compare these defences of scientism with Rosenberg's proposal that 'we'll call the worldview that all us atheists [...] share 'scientism.' This is the conviction that the methods of science are the only reliable ways to secure knowledge of anything; that science's description of the world is correct in its fundamentals; and that when 'complete,' what science tells us will not be surprisingly different from what it tells us today." ${ }^{40}$ In other words, under such an account, there seems to be compelling reason to admit that "scientific inquiry sets the standards for the acceptability of beliefs": ${ }^{41}$ not only does the method of scientific investigation provide a respectable and rigorous standard for the justification of beliefs, the method of scientific investigation and only the method of scientific investigation sets the criteria for acceptability simpliciter. As Paul Boghossian writes, "[w]e take science to be the only good way to arrive at reasonable beliefs about what is true, at least in the realm of the purely factual. Hence, we defer to science." ${ }^{42}$

18 Given this, it would appear Rorty's counter-argument against appealing to Peirce for a pragmatist defence of metaphysics sets up the following problem: Peirce's position is incoherent, ${ }^{43}$ because he is committed to both the indispensability of metaphysics and scientistic naturalism, which sets itself against it. ${ }^{44}$

However, in response to this Rortyan reading of Peirce, I propose that Rorty has a narrow understanding of the sense of metaphysics Peirce believes is indispensable to inquiry, to the extent that he fails to draw an important distinction between transcendent metaphysics and immanent metaphysics: when explicating Rorty's argument against metaphysics, one could see that Rorty takes 'metaphysics' and 'theology' to be equivalent, since they are both typified by "the temptation to look for an escape from time and chance" (Rorty 1989: xiii). As Sachs writes, "Rorty frames his disdain for metaphysics as a radicalisation of Enlightenment disdain for theology, and for much the same reasons: because it represents a stage of our cultural evolution that we need to fully get over, and because it is a threat to liberal democratic institutions." ${ }^{45}$ The question, though, is whether Rorty is justified in thinking 'metaphysics' and 'theology' are equivalent. I contend that Rorty is not justified in making such equivalence, and that Hegel and Peirce arguably provide the strongest arguments to undermine his understanding of metaphysics. 
Hegel, nominalism is inconsistent with the commitments of natural science; and realism about universals is necessarily consistent with the commitments of natural science. Hegel's arguments for those two claims are to be found in the Philosophy of Nature, specifically in those sections of the work which discuss the content and methodology of natural science, what Hegel frequently calls 'empirical physics' (empirische Physik): for Hegel, natural science is empirical, in that it begins with the observation of phenomena in nature. ${ }^{47}$ However, science is not simply an observational discipline in its entirety, as the observations of scientists lead scientists to "identify and describe laws and universal kinds within the multitude of observable natural events and entities." ${ }^{" 48}$ As Hegel himself writes, "[s]cience is a theoretical and thinking consideration of nature [...] [which] aims at comprehending that which is universal in nature [...] forces, laws, genera" (Hegel $1970 \mathrm{I}$ : 196-7). Therefore, according to Hegel, if an inquiry into the natural world fails to establish commitments to universals and laws of nature, which have genuine nomological properties, then that inquiry cannot be a legitimately scientific inquiry. The essence of Hegel's argument here appears to be shared in Peirce's argument that nominalism is inconsistent with the practices of science: ${ }^{49}$ Peirce claims that the nominalist idea of there being no nomological phenomena is incapable of explaining why events/things/processes occur in such a way that is formulated as following a law of nature - i.e. the paraphrasing of propositions committed to non-Humean laws of nature is not something that coheres with how science works. ${ }^{50}$

Above all, what plays a central role in Hegel's criticisms of nominalism and eliminativist attitudes to metaphysics tout court is his ingenious explanation of the significance of metaphysical inquiry in our lives:

It is true that Newton expressly warned physics to beware of metaphysics; but, to his honour, let it be said that he did not conduct himself in accordance with this warning at all. Only the animals are true blue physicists by this standard, since they do not think: whereas humans, in contrast, are thinking beings, and born metaphysicians. All that matters here is whether the metaphysics that is employed is of the right kind: and specifically whether [...] we hold on to one-sided thoughtdeterminations fixed by the understanding, so that they form the basis of our theoretical and of our practical action. (Hegel 1991: §98Z, 156)

What we find here is Hegel's dismissal of the question concerning whether metaphysics tout court is possible, and his insistence on asking the 'real' metametaphysical question, 'What kind of metaphysics is the right kind of metaphysics?' The new metametaphysical challenge posed by Hegel amounts to a litmus test for any metaphysical system to not merely be theoretically satisfying but also practically significant in a specific manner. The specific sense of practical significance I have in mind concerns a broadly perfectionist notion that our general understanding of how all things hang together, to use a Sellarsian turn of phrase, ${ }^{51}$ enables us to achieve at homeness in the world. In other words, the kind of metaphysics we are properly after is going to be sufficiently general/broad (hence not 'one-sided'), and one which is a metaphysics of reason/speculative reflection (hence not 'rigidly fixed by understanding'). The distinction, therefore, between reason (Vernunft) and understanding (Verstand) is going to play a significant role in the development of the right kind of metaphysics. For Hegel, the principal advantage of drawing this distinction between reason and understanding is that we can be in a position to not be wrapped up in the various dualisms which are the inevitable consequence of reflecting only from the perspective of understanding, i.e. purely analytical forms of reflection. ${ }^{52}$ What reason 
provides consciousness with is the means to avoid the pitfalls of dualisms and the problems of analysis by thinking dialectically, ${ }^{53}$ since reason is a "form of holistic explanation, which shows how all finite things are parts of a wider whole." ${ }^{54} \mathrm{~A}$ metaphysics which does not draw this distinction or one which conflates reason with understanding will therefore not be the right kind of metaphysics. This is because failing to draw the distinction between reason and understanding or conflating reason with understanding results in a one-sided conception of thought.

The question we now need to ask is which metaphysical tradition, if any, satisfies Hegel's criteria for the right kind of metaphysics. Of course, a proper answer to such a question is effectively the task of a monograph. However, for the purposes of this paper, I would like to very briefly discuss two metaphysical theses. The first concerns the general metaphysical commitments of ancient Greek philosophy. As Hegel writes:

A philosophy which ascribed veritable, ultimate, absolute being to finite existences as such, would not deserve the name of philosophy; the principles of ancient or modern philosophies, water, or matter, or atoms are thoughts, universals, ideal entities, not things as they immediately present themselves to us, that is, in their sensuous individuality. (Hegel 1969: 154-5)

For Hegel, what is attractive about ancient philosophy is its identification of thought with being - its general commitment to the fundamentally intelligible nature of reality. However, the basic deficiency with ancient metaphysics, one which is also exemplified by the Leibniz-Wolffian tradition, is its commitment to transcendent entities and relations. ${ }^{55}$ So, for all of the attractive features of ancient metaphysics - its commitments to universals and an intelligible structure of reality - it falls short of being the right kind of metaphysics, due to its failure in its exact metaphysical conceptions of the relevant metaphysical phenomena, such as universals. Given this, one may be inclined to suppose that the right kind of metaphysics we are after is going to be provided by immanent metaphysical traditions, such as Spinozism. However, whilst this metaphysical tradition does have an advantage in terms of its broad naturalist commitments, Hegel thinks that such a position is still not the right kind of metaphysics. This is because the philosophical methodology that besets Spinozism, the modo geometrico, is not speculative enough, ${ }^{56}$ and that Spinozism ends up with a monism with no room for individuals. ${ }^{57}$

Both ancient metaphysics and some species of immanent metaphysics have some attractive features for Hegel. To use Moore's expression, both traditions make concerted efforts to make sense of things. However, it must equally be said that due to the various respective failures of both metaphysical traditions, they are both ultimately not able to properly make sense of things. Sense-making, at least in the way I am interpreting Moore's definition of metaphysics, for Hegelians, would require a commitment to a form of naturalism that is both speculative and genuinely immanentist: neither a bifurcation of reality into two ontologically separate realms nor any attempt to reduce some phenomena to basic naturalistic components will do the relevant philosophical work to correctly understand the world we inhabit. What this speculative naturalism aims to accomplish, in its efforts to make sense of things, is to enable us to see that "[t]he empirical is not only mere observing, hearing, feeling, perceiving particulars, but it also essentially consists in finding species, universals and laws." ${ }^{58}$ Like Hegel, Peirce is also focused on establishing the right kind of metaphysics. Contra Rorty, when Peirce writes 
[i]t will serve to show that almost every proposition of ontological metaphysics is either meaningless gibberish [...] or else is downright absurd; so that all such rubbish being swept away, what will remain of philosophy will be a series of problems capable of investigation by the observational methods of the true sciences. (CP: 5.423)

Peirce is not claiming that metaphysics tout court be abandoned and consigned to the flames; rather we should understand Peirce as rejecting a specific genus of metaphysical inquiry, namely traditional onto-categorial metaphysics. In place of traditional categorial ontology, Peirce aims to establish a new metaphysics. I think there is excellent evidence for this when we apply the classic formulation of the Pragmatic Maxim ${ }^{59}$ to concepts such as 'explanation': Peirce aims to clarify the concept of explanation by using all three categories - firstness, secondness, and thirdness. By establishing this holistic approach to explanation, I take Peirce to argue that our explanans of the explanandum illustrates how each specific determination is understood in relation to other determinations. Not only that, though, the way in which each determination is fundamentally interrelated with other determinations illustrates how experience reveals to us an ontologically complex and intelligibly structured order of things, and this is something to which natural scientific investigation is also committed. Understood in this way, I think there is good reason to establish a powerful philosophical link between Hegelian and Peircean metaphysics: both Hegel and Peirce seem to share the project of providing "a systematic critique and overcoming of traditional ontological (categorial) thought in service of an alternative, revisionary metaphysics." ${ }^{60}$ Crucially, what this shows is that Rorty did not see the important difference between the kind of metaphysical project that Hegel and Peirce engender and the kind of metaphysical project he wishes to reject, and that Rorty also mischaracterised Peirce as incoherent.

My pragmatist criticism of Rorty thus far has focused on his narrow conception of metaphysics and his failure to deal with Peirce's Indispensability Argument. However, I think there is an additional pragmatist problem with his metaphilosophical position that pragmatism is opposed to metaphysics tout court: Rorty's Sellarsian philosophical anthropology and his proto-Brandomian theory of the constitution of norms are in fact instances of metaphysical positions.

Like Sellars, Rorty is committed to the 'manifest image of man,' namely a conception of human beings as normative, self-reflecting discursive agents. To quote Putnam on this issue, "[l]et us recognise that one of our fundamental self-conceptualisations, one of our fundamental 'self-descriptions,' in Rorty's phrase, is that we are thinkers." ${ }^{61}$ By conceiving of ourselves qua the manifest image, it would appear that we are doing some variety of metaphysics, where this variety of metaphysics does not require or involve any appeal to onto-theological categories, nor does this variety of metaphysics involve transcending the bounds of sense. Rather, this nuanced genus of metaphysics is a form of naturalism, a naturalism according to which we understand what it is to be a human being in terms of having a particular set of natural capacities, namely a capacity for discursivity and selfconsciousness. So, for Rorty to make sense of his own philosophical anthropological commitments, he must have some metaphysical commitments.

I earlier claimed that the basic notion of value, according to Rorty, undergoes radical critique in the secular age, because we shift from seeing norms as extra-human dictates to seeing norms as, to use Brandom's terminology, "social achievements," in that what is deemed appropriate or inappropriate in a society is not determined by any completely

European Journal of Pragmatism and American Philosophy, VII-2 | 2015 
mind-independent stuff 'out there.' Rather, norms are established by the intersubjective and rational practices between rational agents in a society. By conceiving of the constitution of norms pragmatically, it would appear again that we are doing some variety of metaphysics: firstly, if one rejects the representationalist notion that norms derive their authority from factors independent of social practices, "one needs to have in place a conception of nature as not being the sort of thing that has any authority"; ${ }^{62}$ secondly, if one claims that norms derive their authority exclusively from our social practices, one needs to have in place a conception of normativity as being the sort of thing that is derivable from rational intersubjective practice. Crucially, however, neither conception requires or involves any appeal to onto-theological categories.

If the arguments I have proposed against Rorty have been successful, then one has compelling reason to think his claim that pragmatism is anti-metaphysics tout court is fundamentally mistaken: Rorty is correct to claim that pragmatism is eo ipso opposed to non-humanistic approaches to axiology and rejects transcendent metaphysics, but this does not mean pragmatism is anti-metaphysical. ${ }^{63}$ Moreover, for Rorty to be in a position to make sense of his own philosophical commitments, he must engage in some kind of immanent metaphysical project.

Given the permanent deposit of nuanced metaphysical thought in the American pragmatist tradition, one may well ask 'What are the consequences of debunking Rorty's metaphilosophical interpretation of pragmatism?' Arguably, the clearest consequence of rejecting Rorty's position would appear to be 'reconciling' the post-Kantian idealist tradition with the pragmatist tradition. ${ }^{64}$ The sense of reconciliation I have in mind here is one which melts a barrier that has historically made idealists and pragmatists reluctant to find at homeness with one another, even though there is significant positive philosophical overlap between the two: on the one hand, to pragmatists, idealists represented just the kind of empty and abstract metaphysical theorising that they wanted to overturn; while idealists on the other hand traditionally viewed the pragmatists as failing to resolve the problems that concern them by refusing to metaphysically engage with such problems, offering instead merely a crude appeal to 'practical consequences.' What we have seen is that pragmatism is in fact supportive of a specific variety of metaphysics, a variety for which Hegelianism has considerable affinity; and that, by consequence, the relationship between idealism and pragmatism ought to be seen as involving more convergence rather than great contestation.

\section{BIBLIOGRAPHY}

ALEXANDER T., (1980), “Richard Rorty and Dewey's Metaphysics of Experience," Southwest Philosophical Studies 5, 24-35.

ATKINS P. W., (1995), “The Limitless Power of Science," in J. Cornwell, ed., Nature's Imagination: The Frontiers of Scientific Vision, Oxford, Oxford University Press.

BEISER F. C., (2005), Hegel, New York \& London, Routledge. 
BERNSTEIN R. J., (1980), “Philosophy in the Conversation of Mankind,” Review of Metaphysics 33, 745-75.

BOGHOSSIAN P., (2006), Fear of Knowledge: Against Relativism and Constructivism, Oxford, Oxford University Press.

Bowman B., (2013), Hegel and the Metaphysics of Absolute Negativity, Cambridge, Cambridge University Press.

BRANDOM R., (1994), Making It Explicit, Cambridge, Harvard University Press.

BRANDOM R., (2002), Tales of the Mighty Dead, Cambridge, Harvard University Press.

BRODSKY G., (1982), "Rorty's Interpretation of Pragmatism," Transactions of the Charles S. Peirce Society $17,311-38$.

EDEL A., (1985), “A Missing Dimension in Rorty's Use of Pragmatism,” Transactions of the Charles S. Peirce Society 21, 21-38.

ELLIS B., (2001), Scientific Essentialism, Cambridge, Cambridge University Press.

FISCH M. H., (1974), "Hegel and Peirce," in J. T. O’Malley, K. W. Algozin \& F. G. Weiss, eds., Hegel and the History of Philosophy, The Hague, Martinus Nijhoff.

FORSTER P., (2011), Peirce and the Threat of Nominalism, Cambridge, Cambridge University Press. GILADI P., (2014), "Ostrich Nominalism and Peacock Realism: A Hegelian Critique of Quine," International Journal of Philosophical Studies 22, 734-751.

GOUdGE T., (1950), The Thought of C. S. Peirce, Toronto, Toronto University Press.

HAACK S., (1993), Evidence and Inquiry: Towards Reconstruction in Epistemology, Oxford, WileyBlackwell.

HAACK S., (1995) “Vulgar Pragmatism: An Unedifying Prospect," in H. J. Saatkamp, ed., Rorty and Pragmatism: The Philosopher Responds to his Critics, Nashville, Vanderbilt University Press.

HAACK S., (1998), Manifesto of a Passionate Moderate, Chicago, University of Chicago Press.

HEGEL G. W. F., (1969), Science of Logic, A. V. Miller (trans.), London, Allen and Unwin.

HEGEL G. W. F., (1970), Philosophy of Nature, 3 vols. M. J. Petry (trans.), London, Allen and Unwin.

HEGEL G. W. F., (1975), Aesthetic. Lectures on Fine Art, T. M. Knox (trans.), 2 vols, Oxford, Oxford University Press.

HEGEL G. W. F., (1977a), Phenomenology of Spirit, A. V. Miller (trans.), Oxford, Oxford University Press.

HEGEL G. W. F., (1977b), The Difference Between Fichte's and Schelling's System of Philosophy, H. S. Harris \& W. Cerf (trans.), Albany, State University of New York Press.

HEGEL G. W. F., (1991) The Encyclopaedia Logic, T. F. Geraets, W. A. Suchting, \& H. S. Harris (trans.), Indianapolis/Cambridge, Hackett Publishing Company, Inc.

HEGEL G. W. F., (1995), Lectures on the History of Philosophy, E. S. Haldane (trans.), Lincoln, University of Nebraska Press

HoUlgate S., (2007) "Hegel and Brandom on Norms, Concepts and Logical Categories," in E. Hammer, ed., German Idealism: Contemporary Perspectives, London, Routledge.

JAMES W., (1996), A Pluralistic Universe, Lincoln, University of Nebraska Press. 
JAMES W., (2000), Pragmatism: A New Name for some Old Ways of Thinking, in The Works of William James, London, Penguin Books.

JAMES W., (2003), Essays in Radical Empiricism, London/New York, Dover Publications.

KITCHER P., (2008), “Science, Religion, and Democracy,” Episteme 5, 5-18.

LOWE E. J., (1998), The Possibility of Metaphysics, Oxford, Oxford University Press.

LOWE E. J., (2002), A Survey of Metaphysics, Oxford, Oxford University Press.

LOWE E. J., (2006), The Four-Category Ontology: A Metaphysical Foundation for Natural Science, Oxford, Oxford University Press.

LEAR J., (1988), Aristotle: The Desire to Understand, Cambridge, Cambridge University Press.

MISAK C., (2013), The American Pragmatists, Oxford, Oxford University Press.

MOORE A. W., (2012), The Evolution of Modern Metaphysics: Making Sense of Things, Cambridge, Cambridge University Press.

NIETZSCHE F., (2001) The Gay Science, J. Nauckhoff (trans.), New York, Cambridge University Press. Nuzzo A., (ed.), (2010), Hegel and the Analytic Tradition, London, Continuum.

ODERBERG D. S., (2007), Real Essentialism. New York, Routledge.

PEIRCE C. S., (1931-1958), Collected Papers of Charles Sanders Peirce, 8 vols, C. Hartshorne, P. Weiss, \& A. W. Burks, eds., vols. 1-6, 1931-1935; vols. 7-8 edited by A. W. Burks, 1958, Cambridge, Harvard University Press.

PEIRCE C. S., (1982) Writings of Charles S. Peirce: A Chronological Edition, currently 6 vols., M. Fisch, E. Moore, \& C. Kloesel, eds., Bloomington, Indiana University Press.

PEIRCE C. S., (1992 and 1998), The Essential Peirce, 2 vols., N. Houser, C. Kloesel, and the Peirce Edition Project, eds., Bloomington, Indiana University Press.

PINKARD T., (2007) “Was Pragmatism the Successor to Idealism?," in C. Misak, ed., New Pragmatists, Oxford, Clarendon Press.

PUTNAM H., (1981), Reason, Truth, and History, New York, Cambridge University Press.

PUTNAM H., (1983), “Why Reason Can't be Naturalised," in his Realism and Reason: Philosophical Papers, Volume 3, Cambridge, Harvard University Press.

RAMBERG B., (2008), "Rorty, Davidson, and the Future of Metaphysics in America," in C. Misak, ed., The Oxford Handbook of American Philosophy, New York, Oxford University Press.

RORTY R., (1982), Consequences of Pragmatism, Minneapolis, University of Minnesota Press.

RORTY R., (1989), Contingency, Irony, and Solidarity, New York, Cambridge University Press.

RORTY R., (1991), Objectivity, Relativism, and Truth: Philosophical Papers, 4 vols., Volume 1, Cambridge, Cambridge University Press.

RORTY R., (1995), “Response to Richard Bernstein,” in H. J. Saatkamp, ed., Rorty and Pragmatism: The Philosopher Responds to his Critics, Nashville, Vanderbilt University Press.

RORTY R., (2000) “Response to Jürgen Habermas," in R. Brandom (ed.) Rorty and his Critics, Oxford, Oxford University Press. 
RORTY R., (2001) “Justice as a Larger Loyalty," in M. Festenstein \& S. Thompson, eds., Richard Rorty: Critical Dialogues, Malden, Polity.

RORTY R., (2002) “Words or Worlds Apart? The Consequences of Philosophy for Literary Studies," Philosophy and Literature 26, 369-96.

RORTY R., (2010), “Intellectual Biography,” in R. Auxier \& L. Hahn, eds., The Philosophy of Richard Rorty, Chicago, Open Court.

ROSENBERG A., (2011), The Atheist's Guide to Reality: Enjoying Life without Illusions, New York/London, W. W. Norton \& Co.

SACHS C. B., (2013), “Rorty's Debt to Sellarsian Metaphysics: Naturalism, Secularisation, and the Enlightenment," Metaphilosophy 44, 682-707.

SCHERMER M., (2002), Why People Believe Weird Things: Pseudoscience, Superstition, and Other Confusions of Our Time, New York, Henry Holt \& Co.

SCHILLER F. C. S., (1903), Humanism: Philosophical Essays, London, MacMillan.

SCHILLER F. C. S., (1910), Riddles of the Sphinx, London, Swan.

SELLARS W., (1963), "Philosophy and the Scientific Image of Man," in R. Colodny, ed., Frontiers of Science and Philosophy, Pittsburgh, University of Pittsburgh Press.

SLEEPER R., (1985), “Rorty's Pragmatism: Afloat in Neurath's Boat, But Why Adrift?," Transactions of the Charles S. Peirce Society 21, 9-20.

STERN R., (2007), "Hegel, British Idealism, and the Curious Case of the Concrete Universal," British Journal for the History of Philosophy 15, 115-153.

STERN R., (2008), "Hegel's Idealism," in F. C. Beiser, ed., The Cambridge Companion to Hegel and Nineteenth-Century Philosophy, Cambridge, Cambridge University Press.

STERN R., (2009), Hegelian Metaphysics, Oxford, Oxford University Press.

STONE A., (2004), Petrified Intelligence: Nature in Hegel's Philosophy, Albany, State University of New York Press.

\section{NOTES}

1. Rorty (1982: 80).

2. I take my lead from Adrian Moore's definition of metaphysics: "Metaphysics is the most general attempt to make sense of things" (A. W. Moore 2012:1).

3. Putnam (1981: 49).

4. Rorty (1982: 13).

5. Rorty (2001: 89).

6. Rorty (1982: xxviii).

7. Rorty (2002: 391).

8. See James (2000: 28$)$.

9. Sachs (2013: 700)

10. Brandom (2002: 216).

11. Houlgate (2007: 139).

12. Brandom (1994: 647). 
13. There is also good reason to suppose James's and F. C. S. Schiller's explicit hostility to Hegel may in fact be rather misplaced: had James and Schiller (and Peirce to some extent) had really known Hegel, rather than understood Hegel via the distorted view of him presented by F. E. Abbot, Royce and the British Idealists, James and Schiller (and Peirce to some extent) may have had a far more positive attitude to Hegel. For all of James's and Schiller's caustic criticisms of Hegel as being guilty of abstract metaphysical speculation, their respective critiques of abstract metaphysics seems to echo Hegel's famous Inverted World hypothesis, which is a landmark criticism of transcendent metaphysics. See Stern 2009 for further on Hegel's reception by Peirce and James.

14. See Schiller (1910: 160), and Schiller (1903: 98-9).

15. In writing 'pure inquiry,' I am using Bernard Williams's characterisation of the Cartesian philosophical project.

16. Rorty himself claims that his own philosophical commitments "tend to centre around James's version [...] of the pragmatic theory of truth" (Rorty 1995: 71).

17. See James (2000: 15).

18. The lack of phenomenological robustness is not the only problem with the Cartesian representationalist tradition, according to Jamesian pragmatism. For James, another serious failing of rationalism and in fact the early modern era in general - where only Reid and Berkeley appear to radically depart from their contemporaries - is the preference for advocating indirect/ representational realist theories of perception. As James writes, “'Representative' theories of perception [...] violate the reader's sense of life, which knows no intervening mental image but seems to see the room and the book immediately just as they physically exist" (James 2003: 6).

19. Brandom (2002: 216).

20. As Cheryl Misak writes on the James-Rorty relationship, "it is tempting to think of [Rorty] as contemporary pragmatism's William James” (Misak 2013: 225).

21. See also (James 2003: 100-1).

22. "Forget, for the moment, about the external world, as well as about that dubious interface between self and world called 'perceptual experience"' (Rorty 1991: 93).

23. Rorty (1982: xlii).

24. Misak (2013: 230).

25. "But when will we be done with our caution and care? When will all these shadows of god no longer darken us? When will we have completely de-deified nature? When may we begin to naturalise humanity with a pure, newly discovered, newly redeemed nature?" (Nietzsche 2001: 109).

26. Rorty (1982: xiii).

27. Rorty (1991: 36).

28. See, for example, Haack 1995.

29. Rorty (2000: 60).

30. What is interesting to note here is how Dewey takes pragmatism's commitment to expanding the frontiers of inquiry and foster more and more intersubjectivity to express its essential link to democracy. Rorty, however, does not think there is a link between pragmatism and democracy.

31. Brandom (1994: 647).

32. See also (CP: 1.229) and (CP: 7.579).

33. Stern (2009: 4).

34. Oderberg (2007: 43).

35. See Ellis 2002 and Lowe 2006 for an excellent critique of anti-metaphysics.

36. Lowe (1998: v).

37. See also: "[P]hilosophy is either a science or it is balderdash" (CP: 5.13).

38. Shermer (2002: 35).

39. Atkins (1995: 132). 
40. Rosenberg (2011: 6-7).

41. Kitcher (2008: 11).

42. Boghossian (2006: 4).

43. As Thomas Goudge writes, "Peirce's ideas fall naturally into two broad groups whose opposite character is a reflection of a deep conflict in his thinking [...] the result of his conflicting commitment to both naturalism and transcendentalism" (Goudge 1950: xx).

44. See the following quote by Rorty: "That mixture of logic-worship, erudition, and romance was reminiscent of Peirce, with whose writings I had spent a lot of time, hoping to discover the non-existent secret of his non-existent 'system' [...] Sellars and Peirce are alike in the diversity and richness of their talents, as well as in the cryptic style in which they wrote. But Sellars, unlike Peirce, preached a coherent set of doctrines." (Rorty 2010: 8).

45. Sachs (2013: 684).

46. See Stern 2008.

47. Cf. Hegel (1970 I: 193).

48. Stone (2004: 2-3).

49. Peirce's Hegelianism is in need of qualification: occasionally, Peirce appears to be greatly indebted to Hegel, whereas he also sometimes appears extremely dismissive of him. See (CP: 6.293-5) for an example of Peirce's fondness and contempt for absolute idealism. See Fisch 1974 and Stern 2009 for Peirce's complex relationship with Hegel.

50. Cf. 5.210. He also claims that nominalism's rejection of universals and laws of nature make it "anti-scientific in essence" (2.166). Peirce's many arguments that nominalism is anti-scientific are, in fact, Hegelian arguments: however, Peirce's claims to this effect have often been better received and viewed more seriously than Hegel's, perhaps because the former's relation to and understanding of empirical science has generally been taken to be more credible than Hegel's. See Stern 2009 for an excellent discussion of Hegel and Peirce's category of thirdness. See Forster 2011 for an excellent discussion of Peirce's arguments against nominalism.

51. W. Sellars (1963: 35).

52. See Hegel (1975 I: 99-100).

53. See Hegel (1991: §164Z, 240). For further discussion of this subject, see Stern 2007 and Giladi 2014.

54. F. C. Beiser (2005: 165).

55. Aristotle would seem to be an awkward metaphysician to deal with, given his commitment to a form of objective idealism - cf. Lear 1988 and Stern 2008 - and also to some transcendent notions, such as an immaterial divine intellect.

56. Hegel (1977b: 105), and Hegel (1977a: §48).

57. See (Hegel 1995: 258).

58. (Hegel 1995: 176).

59. See (CP: 5.402).

60. Bowman (2013: 7). I acknowledge, though, that a pragmatist critic of Hegel will insist that Peirce's metaphysics is more a posteriori and empirically informed than Hegel's speculative synthetic a priorism.

61. Putnam (1983: 246).

62. Sachs (2013: 701). See also the following quote from Terry Pinkard: "To understand ourselves as having such a self-instituted liberation from nature, however, required us to understand nature itself as disenchanted, as lacking normative authority on its own" (Pinkard 2007: 149).

63. For further on this tradition of criticising Rorty, see the following works: Alexander 1980, Bernstein 1980, Brodsky 1982, Edel 1985, Sleeper 1985, Haack 1993, 1995, 1998, and Ramberg 2008. 64. I write 'reconciling,' because I think the kind of rapprochement between Hegelian idealism and pragmatism is importantly different to the kind of rapprochement between Hegelianism and the Anglo-American naturalist philosophic tradition: Hegel came to be arguably the main target 
of attack by the founders of the analytic movement, Bertrand Russell and G. E. Moore. To quote Angelica Nuzzo on this issue: "Rudolf Carnap's seminal attacks to metaphysical thinking of which Hegel was seen as the champion, as well as Bertrand Russell's and G. E. Moore's rejection of his 'idealism' have sufficed to make the case for the radical distance separating Hegel from analytic philosophy in its very inception" (Nuzzo 2010: 1). In other words, analytic philosophy was founded squarely to repel and defeat Hegelianism. The pragmatists, however, had a more complex reaction to Hegel: Dewey was rather sympathetic to Hegelianism; James loathed (what he understood to be) Hegelian idealism; Peirce admired and loathed Hegelian thought in seemingly equal measure; and more recently, Brandom claims to have had a far-reaching debt to Hegel.

\section{ABSTRACTS}

The aim of this paper is to argue that Richard Rorty's claim that pragmatism is opposed to all varieties of metaphysics is fundamentally mistaken. After detailing pragmatist reasons for thinking Rorty's proposal is justified, I argue that there are more compelling pragmatist reasons to think Rorty's metaphilosophical interpretation of pragmatism is rather problematic: firstly, Rorty has a narrow understanding of 'metaphysics' and he does not take into account Peirce's argument that it is impossible to eliminate metaphysical concepts from ordinary language and our scientific practices; secondly, Rorty's Sellarsian philosophical anthropology and his protoBrandomian theory of the constitution of norms are in fact instances of metaphysical positions. I conclude the paper by claiming that given that pragmatism is in fact supportive of a specific variety of metaphysics, the relationship between idealism and pragmatism ought to be seen as involving more convergence rather than great contestation.

\section{AUTHOR}

\section{PAUL GILADI}

University of Sheffield

paul.giladi[at]gmail.com] 